\title{
Contrasting Impacts of Three Types of ENSO Event on Boreal Autumn Rainfall over Southwest China
}

\author{
Jiajie Hu, Wei Wang*, Yining Tan
}

College of Atmospheric Sciences, Chengdu University of Information Technology, Plateau Atmosphere and Environment Key Laboratory of Sichuan Province, Chengdu, China

Email: 1471738212@qq.com, ${ }^{*}$ wei2009@cuit.edu.cn,1079606937@qq.com

How to cite this paper: $\mathrm{Hu}, \mathrm{J}$. J., Wang, W., \& Tan, Y. N. (2021). Contrasting Impacts of Three Types of ENSO Event on Boreal Autumn Rainfall over Southwest China. Journal of Geoscience and Environment Protection, 9, 14-27.

https://doi.org/10.4236/gep.2021.910002

Received: September 7, 2021

Accepted: October 16, 2021

Published: October 19, 2021

Copyright $\odot 2021$ by author(s) and Scientific Research Publishing Inc. This work is licensed under the Creative Commons Attribution International License (CC BY 4.0).

http://creativecommons.org/licenses/by/4.0/

\begin{abstract}
The autumn precipitation over southwest China is one of the main causes of meteorological disasters. Using observed monthly station rainfall data and HadISST and NCEP/NCAR analysis data, the impacts of three types of El Niño-Southern Oscillation (ENSO) events on the boreal autumn rainfall over southwest China were determined. Over southwest China, autumn rainfall constitutes $>20 \%$ of the total annual rainfall and a marked decline in autumn rainfall commenced around 1990. During La Niña events, there is surplus (deficit) over the middle (northwest and southeast) of southwest China. In cnetral Pacific (CP) El Niño events, the autumn rainfall anomaly shows a deficiency over China. The large-scale atmospheric circulation anomalies in the three ENSO categories also exhibit distinct characteristics. During CP El Niño autumns, the pressure anomaly over the North Pacific Ocean displays a "-+-" structure, with a high-pressure anomaly over the Asian continent. An anomalous cyclone appears over the western North Pacific (WNP). In EP El Niño autumns, the pressure anomaly over the North Pacific Ocean has a "+-" structure, with a low-pressure anomaly over the Asian continent. An anomalous anticyclone appears over the WNP and the 500-hPa anomalies are opposite to those of CP El Niño events. During La Niña autumns, the characteristics of circulation present the opposite structure to those of CP El Niño events. This work is of certain significance for an in-depth understanding of the impacts of ENSO on the autumn precipitation over southwest China.
\end{abstract}

\section{Keywords}

El Niño-Southern Oscillation, Autumn Rainfall, Integrated Water Vapor Transport, Southwest China 


\section{Introduction}

The rainfall peak of most regions of China is during summer due to the effects of the East Asian monsoon. In addition to the main summer peak, a second rainfall peak appears in autumn in some areas. The most typical autumn rain phenomenon is observed in southwest China and is known as the Huaxi $\left(104^{\circ} \mathrm{E}\right.$ $112^{\circ} \mathrm{E}, 29^{\circ} \mathrm{N}-38^{\circ} \mathrm{N}$ ) autumn. Huaxi autumn rain is one of the main causes of meteorological disasters in southwest China. Study of autumn rains in southwest China began during the 1930s, and numerous studies of the characteristics and mechanism of the Huaxi autumn rain have been published (Zhang, 1941; Lv, 1942; Gao, 1958; Liang, 1989; Bai \& Dong, 2004; Wang \& Ding, 2008; Bao et al., 2003; Kuang et al., 2008; Liu et al., 2012). Bao et al. (2020) analyzed the anomalous features of summer monsoon circulations in 2017 with extremely strong autumn precipitation Huaxi over eastern Chian, and explored the mechanisms. $\mathrm{Xu}$ et al. (2020) investigated the interdecadal change of autumn rainfall in western China. Chen et al. (2020) analyzed the interdecadal variability of autumn rain in West China from 1961 to 2014 and its relationship with atmospheric circulation and sea surface temperature. Zheng et al. (2018) studied the relationship between Huaxi autumn rain intensity and summertime heat content in the western Pacific warm pool.

A phenomenon of widespread concern, the El Niño-Southern Oscillation (ENSO) has a significant influence on weather and climate around the globe (Bjerknes, 1969; Van Loon \& Madden, 1981; Ropelewski \& Halpert, 1987; Dong et al., 2000; Zanchettin et al., 2008). For example, numerous studies of recent El Niño events have indicated that the El Niño has a pivotal role in the Madden-Julian oscillation (Zhang \& Gottschalck, 2002; Kapur \& Zhang, 2012). As two large-scale phenomena of the global climate system, the connections between the Asian monsoons and ENSO have been examined in numerous studies (Webster \& Yang, 1992; Lin \& Yu, 1993; Zhi et al., 2012; Wang et al., 2012; Yuan et.al., 2014; He et al., 2015). Zhang et al. (2021) analyzed the characteristics of atmospheric circulation for the spring precipitation anomalies in Jiangxi and its response to ENSO events. Liang et al. (2021) extensively examined the impacts of El Niño events on boreal summer rainfall over the East Asian Monsoon and South Asian Monsoon regions and their associated mechanisms. Recent studies have indicated that: there are two types of El Niño: the conventional El Niño, referred to as eastern Pacific (EP) El Niño, and a new type of El Niño called central Pacific (CP) El Niño (Larkin \& Harrison, 2005; Ashok et al., 2007; Kao \& Yu, 2009; Kug et al., 2009). Yeh et al. (2009) reported that EP El Niño has been less common, whereas CP El Niño has occurred more often since the early 1990s. Moreover, for the cold episodes of ENSO (La Niña), the zonal location of sea surface temperature (SST) anomalies has shown no significant change. The characteristics of the different types of ENSO and their impacts have been addressed in numerous studies (Ren \& Jin, 2011; Feng \& Li, 2013; Yuan et al., 2012, 2014; Zhang et al., 2011, 2014; He et al., 2015). The two types of El Niño events have highlighted the 
importance of the central Pacific. Zhao et al. (2021) showed that the local correlation between ENSO subsurface temperatures in the upper 100-m and thermocline depth anomalies breaks down in the central equatorial Pacific, whereas Tsub remains well correlated with sea surface height anomalies.

West China is one of the main autumn precipitation regions in China, and the autumn rainfall over this region is one of the main causes of meteorological disasters. Meanwhile, the characteristics of ENSO have highlighted the importance of the precipitation over China, especially the impacts of different types of ENSO. So, whether the shift of ENSO types gives rise to the change of autumn rainfall over southwest China needs to be studied. This study focuses on the characteristics of the different ENSO types and their possible effects on autumn rainfall over southwest China.

\section{Data and Methodology}

For rainfall analysis, we mainly used the monthly station rainfall data (1961-2015) supplied by the China Meteorological Administration. The Hadley Centre Global Sea Ice and Sea Surface Temperature (HadISST) analyses data sets (Rayner et al., 2003) from January 1961 to December 2015 were mainly used in this study. For identification of warm or cold ESNO episodes, the Nino3.4 index from January 1961 to March 2016 supplied by Climate Prediction Center (CPC) was used. In this study, atmospheric circulation was examined using the National Centers for Environmental Prediction/National Centers for Atmospheric Research (NCEP/NCAR) reanalysis products (Kalnay et al., 1996) such as the sea level pressure, geopotential height, and wind data sets for 1961 to 2015.

Anomalies for all variables were computed as the deviation from the 30 -year climatological mean (1971-2000). In this study, we focus on the boreal autumn (September-November (SON)) season.

Vertically integrated water vapor transport (IVT) is vertically integrated from the surface to $300 \mathrm{hPa}$ with monthly data over the globe, but herein only data for the area $10^{\circ} \mathrm{S}-50^{\circ} \mathrm{N}, 90^{\circ} \mathrm{E}-160^{\circ} \mathrm{W}$ are displayed. Data for wind, geopotential height, and specific humidity fields were obtained from NCEP/NCAR reanalysis.

\section{Results}

\subsection{Autumn Rainfall of Southwest China}

Figure 1 displays autumn rainfall as a proportion of total annual rainfall for China. Over southwest China, autumn rainfall accounts for more than $20 \%$ of the total annual rainfall, in particular more than $25 \%$ over the Huaxi region $\left(104^{\circ} \mathrm{E}-112^{\circ} \mathrm{E}, 29^{\circ} \mathrm{N}-38^{\circ} \mathrm{N}\right)$ and the southwest of Yunnan Province. Figure 2 displays the standard time series of autumn rainfall anomaly over the Huaxi region from 1961 to 2015 . The standard time series displays a marked decline in autumn rainfall commencing around 1990. Based on the moving $t$ test technique, there was a striking and significant decadal abrupt change in 1990. Prior to 1990 , autumn rainfall over the Huaxi region was dominated by interannual 


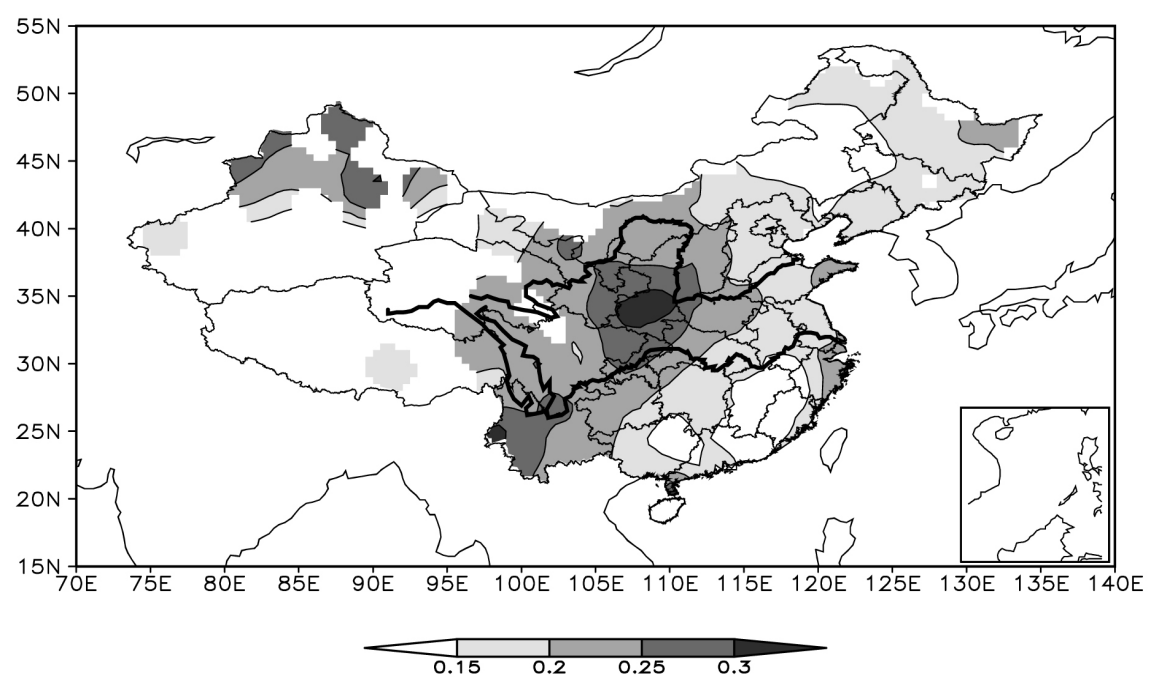

Figure 1. Autumn rainfall as a proportion of total annual rainfall in China.

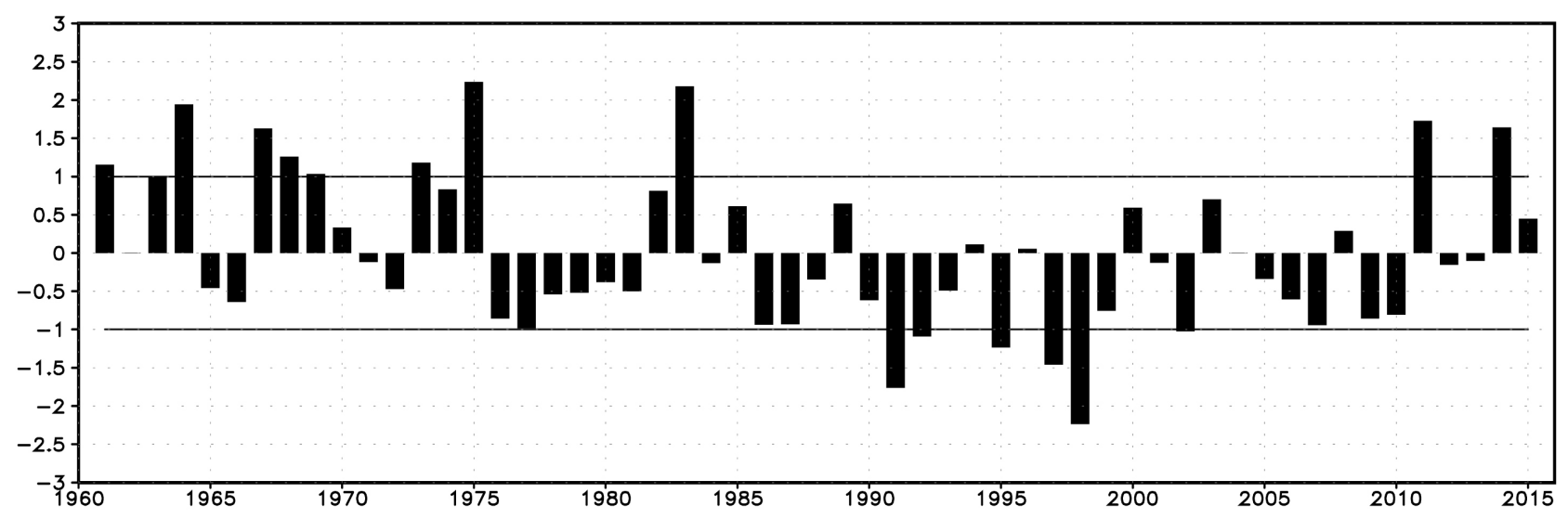

Figure 2. Time standard series of $\mathrm{SON}$ rainfall over the Huaxi region $\left(104^{\circ} \mathrm{E}-112^{\circ} \mathrm{E}, 29^{\circ} \mathrm{N}-38^{\circ} \mathrm{N}\right)$. The block lines represent \pm 1 standard deviation.

variability with oscillations between surplus and deficit. After 1990, autumn rainfall over the Huaxi region is dominated by deficits until 2011. Thus, during the 1990s and 2000s, the prevalent rainfall deficits caused frequent autumn droughts.

\subsection{Three Types of ENSO Events}

Based on lagged correlation between the time series of SON rainfall and the Nino3.4 SST anomaly in each month from the present year to the following year, there is no significant linear correlation (not illustrated). However, there is a connection between the autumn rainfall over southwest China and ENSO. Numrous recent studies have shown that there are two types of El Niño. Yeh et al. (2009) indicated that EP El Niño events are less common, whereas CP El Niño events have occurred more often since the early 1990s. We studied the changes in ENSO on the basis of the Nino3.4 index. Figure 3 displays the evolution of the Nino3.4 index (in bar) from January 1961 to March 2016. Based on 

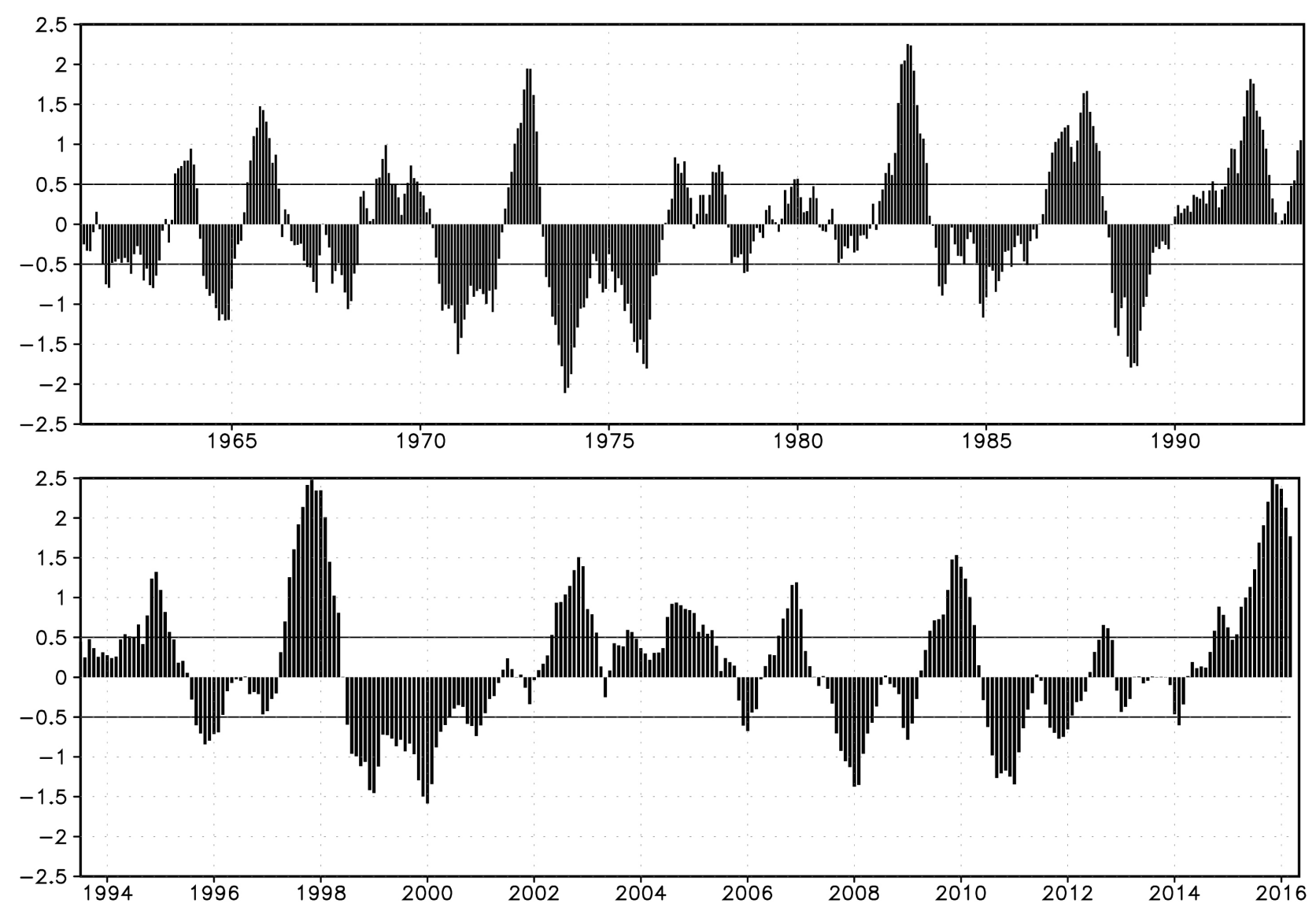

Figure 3. Anomaly time series of the Nino3.4 index ( ${ }^{\circ} \mathrm{C}$, bar) from January 1961 to May 2016 . The solid thin lines denote $\pm 0.5^{\circ} \mathrm{C}$.

the definition of ENSO, we used the Nino3.4 SST anomaly time series to identify fifteen El Niño and eleven La Niña events (Table 1). We list the start and end time for each warm or cold ENSO episode. We selected episodes that extended over September, October, and November. Finally, we identified thirteen El Niño autumns (1963, 1965, 1972, 1982, 1986, 1987, 1991, 1997, 2002, 2004, 2006, 2009, and 2015) and eleven La Niña autumns (include 1964, 1970, 1971, 1973, 1975, 1988, 1995, 1998, 1999, 2007, and 2010).

Figure 4 and Figure 5 display the SST anomaly of all El Niño events during the period 1961-2015. The displayed values are the mean of SST anomaly from September to November in each El Niño year. It can be noted that each event has a unique characteristic, so there are thirteen spatial patterns; however, it is possible to classify these events into two groups on the basis of the zonal location of the equatorial sea surface temperature anomalies (SSTA).

Six El Niño events show stronger SSTA in the central Pacific and small positives anomalies in the western and eastern Pacific. Because the cation centre of the SSTA is located in the central Pacific area, we call this group CP El Niño. Figure 4 shows the central Pacific (CP) El Niño, which are the events of 1986, 1991, 2002, 2004, 2006, and 2009. Most of these events occurred after 1990, so this type of El Niño was very active in recent decades. 

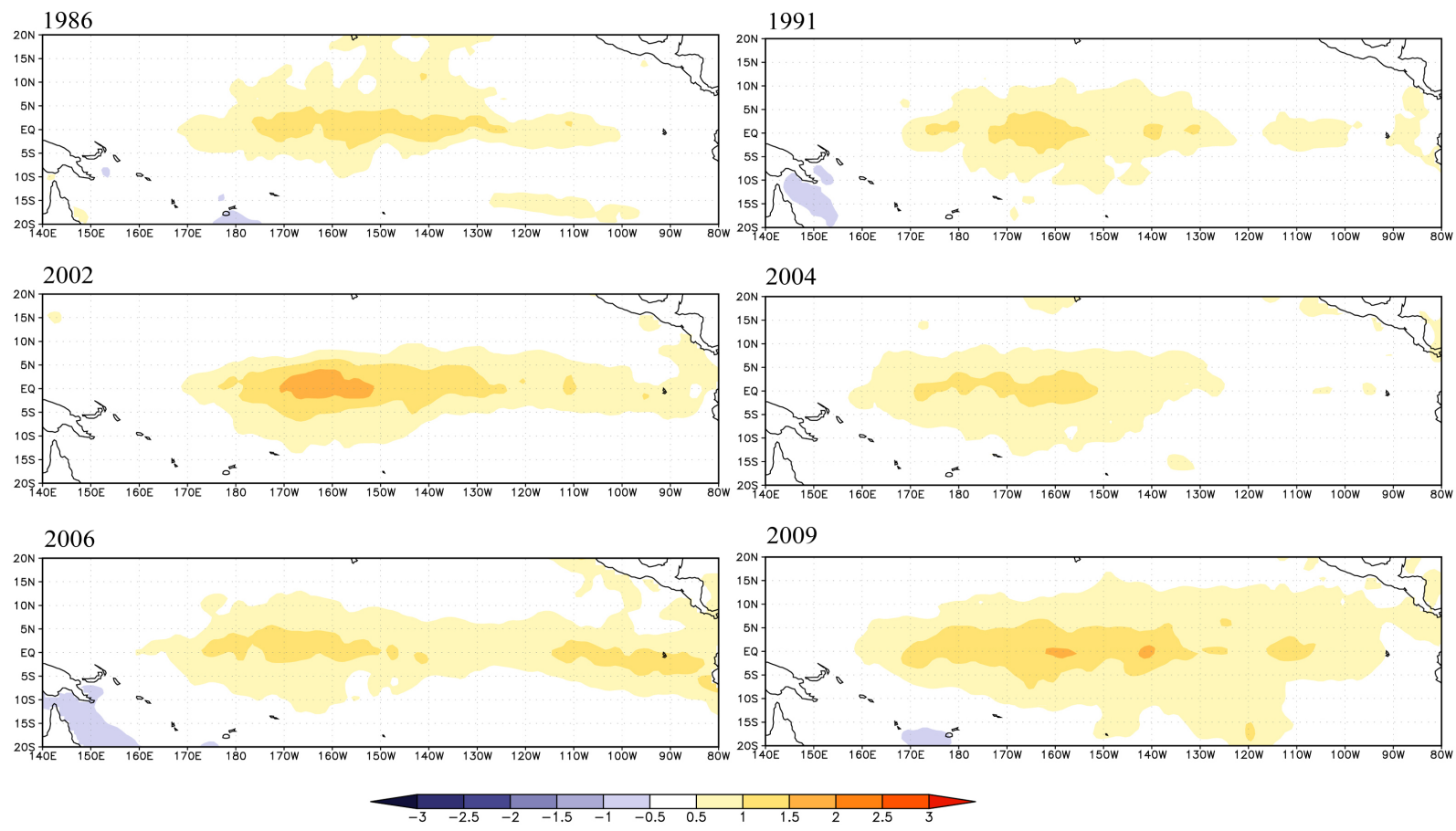

Figure 4. SST anomalies $\left({ }^{\circ} \mathrm{C}\right)$ of El Niño Events during 1961-2015. The anomalies are averaged from September to November. El Niño events are classified into Central Pacific (CP) El Niño (this figure), and eastern Pacific (EP) El Niño (Figure 5).
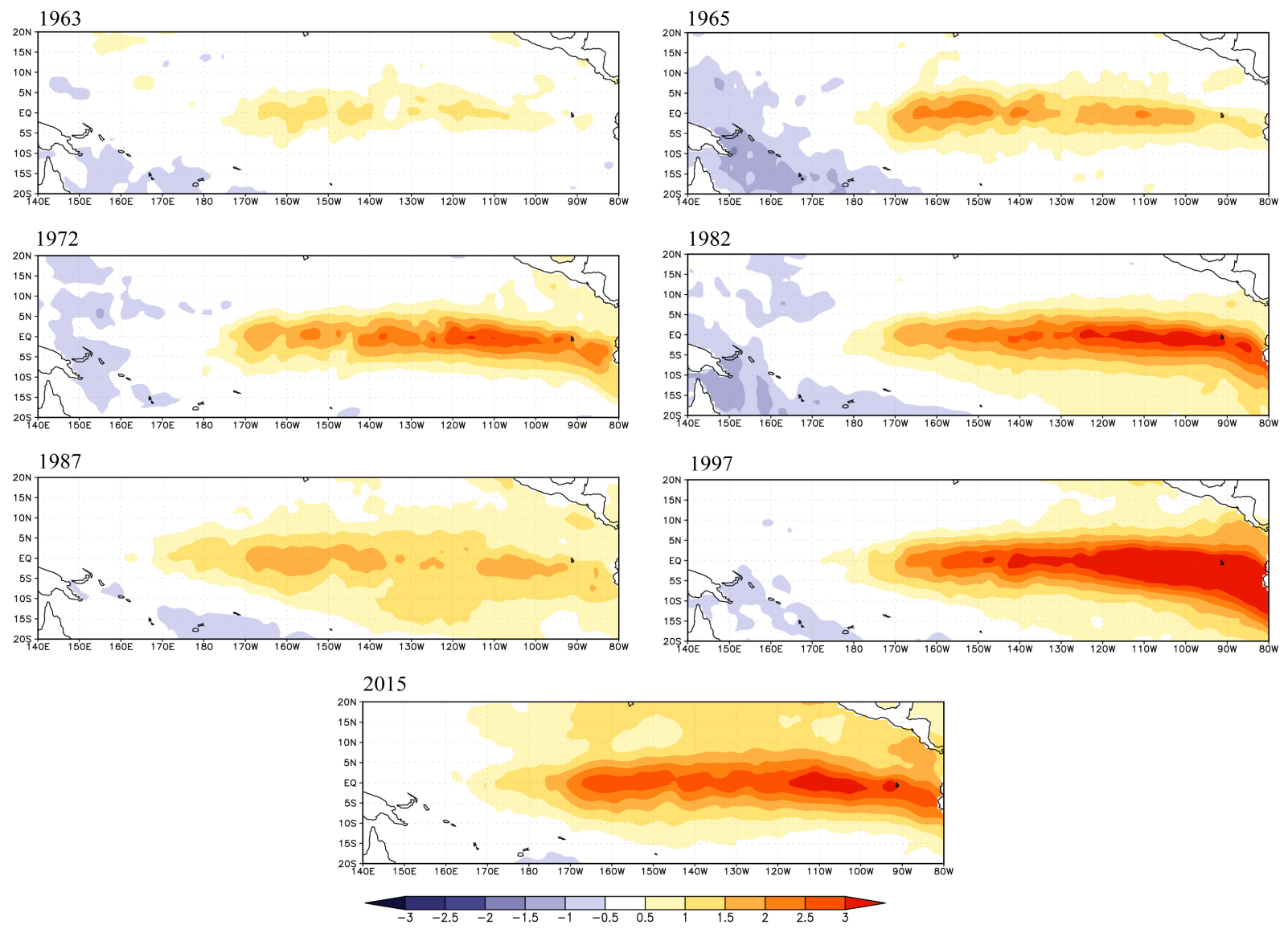

Figure 5. Same as Figure 4, but for the eastern Pacific (EP) El Niño events. 
Table 1. Warm and cold episodes, identified on the basis of a threshold of $\pm 0.5^{\circ} \mathrm{C}$ for the Nino3.4 region SST anomaly from January 1961 to December 2015.

\begin{tabular}{cl}
\hline & \multicolumn{1}{c}{ Start and end times (year and month) } \\
\hline \multirow{3}{*}{ El Niño } & $1963.7-1964.1,1965.3-1966.3,1968.11-1969.4,1972.6-1973.2$, \\
& $1982.5-1983.6,1986.9-1988.1,1991.6-1992.7,1994.10-1995.3$, \\
& $1997.5-1998.5,2002.5-2003.3,2004.7-2005.5,2006.8-2007.1$, \\
& $2009.6-2010.4,2015.3-2016.3$ \\
La Niña & $1964.4-1965.1,1967.12-1968.5,1970.7-1972.1,1973.5-1974.7$, \\
& $1975.2-1976.4,1984.10-1985.5,1988.5-1989.5,1995.9-1996.2$, \\
& $1998.7-2000.5,2007.9-2008.5,2010.7-2011.3$ \\
\hline
\end{tabular}

For the second group, unlike the CP El Niño events, the stronger SSTA of these El Niño events is in the eastern Pacific and always extends to the central Pacific. Because the caution centre of the SSTA is located in the eastern Pacific area, so we call this group EP El Niño. This group includes the 1963, 1965, 1972, 1982, 1987, 1997, and 2015 El Niño events (Figure 5). The SSTA distribution of this group is quite similar to that of the conventional El Niño (Harrison \& Larkin, 1998). It is interesting that the strongest El Niño events since 1950 are included in this group, such as 1972-73, 1982-83, 1997-98.

We also investigated the SSTA distribution of all La Niña events during 1961-2015 (not illustrated). The SSTA distributions of the La Niña events are similar to each other. This result agrees with the finding of other studies (Yeh et al., 2009).

\subsection{Autumn Rainfall Anomalies during ENSO}

We used composite analyses to further investigate the possible relationship between the shift in ENSO types and autumn rainfall over southwest China. Using the classification of ENSO described above, we composited the SON rainfall anomalies.

Figure 6 displays the composites SON rainfall anomalies based on the ENSO classification. during La Niña events, a "+-+" structure from west through east in autumn rainfall anomalies appears over China, with the distribution of the rainfall anomaly being southwest-northeast. There is a rainfall surplus over the middle of southwest China and a deficit over the northwestern and southeastern areas of southwest China (Figure 6(c)). During EP El Niño events, there is a "+-" dipolar structure from south through north in autumn rainfall anomalies over China, with a surplus to the south of the Yangtze River and a deficit to the north of the Yangtze River and in the western of southwest China (Figure 6(b)). In contrast, for $\mathrm{CP}$ El Niño events, the autumn rainfall anomaly displays a deficit over China (Figure 6(a)).

Note that remarkably different rainfall anomalies occur during the different types of ENSO: for CP El Niño events, the autumn rainfall anomaly shows regional homogeneity that is all deficit; for EP El Niño events, the autumn rainfall anomaly displays an east-west distribution with a deficit in the west and a surplus 


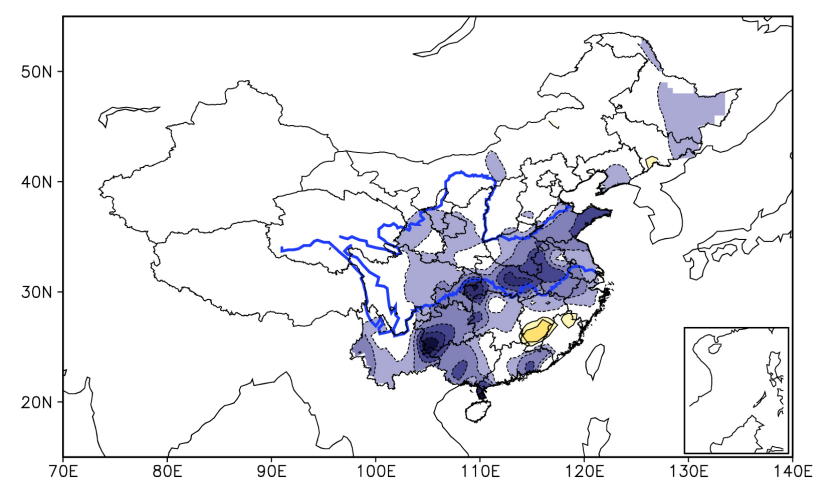

(a)

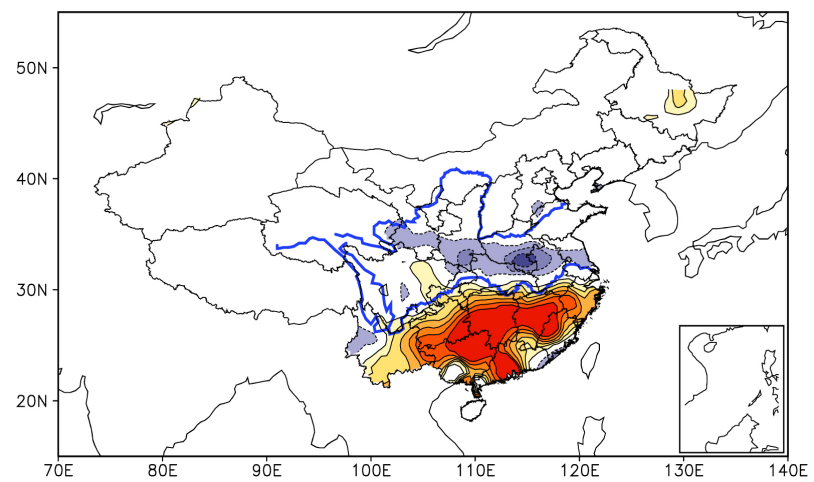

(b)

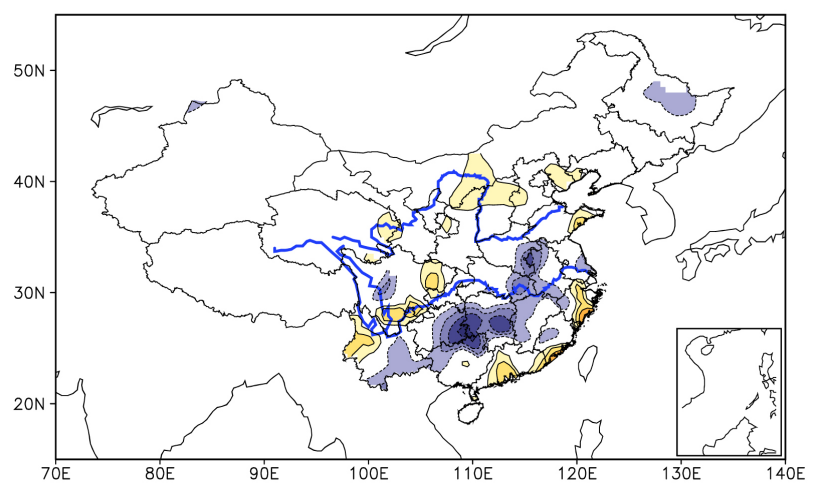

(c)

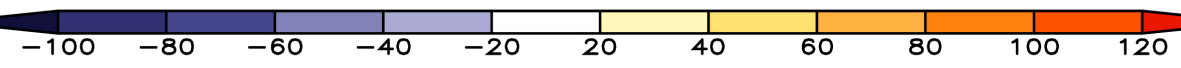

Figure 6. Composites maps of SON rainfall anomalies (mm) for (a) CP El Niño, (b) EP El Niño, and (c) La Niña events.

in the east; and for La Niña events, the autumn rainfall anomaly is southwestnortheast with a deficit in the west and east and a surplus in the middle. Thus, autumn rainfall over southwest China is closely associated with different types of ENSO events.

\subsection{Autumn SST and Circulation Anomalies during ENSO}

Because the differences in rainfall are associated with the atmospheric responses to the three types of ENSO, Figure 7 and Figure 8 display composites of SON SSTA and SLP anomalies, vertically integrated water vapor transport anomalies, and 500-hPa geopotential height anomaly for CP El Niño, EP El Niño, and La Niña events.

Figure 7 displays composite maps of the boreal autumn SST anomaly and SLP anomalies for the three ENSO categories. Comparing CP and EP El Niño events, we can note that EP Niño (Figure 7(b)) years show a broad positive SST anomaly extending from $180^{\circ}$ to the South American coast, and the maximum SST anomaly in CP El Niño events (Figure 7(a)) is reduced in magnitude and shifted westward toward the central equatorial Pacific Ocean relative to EP El Niño events (Figure $7(\mathrm{~b})$ ). This finding is similar to the results of previous studies (Kug et al., 2009; Kim \& Alexander, 2015). In contrast in the western Pacific and 


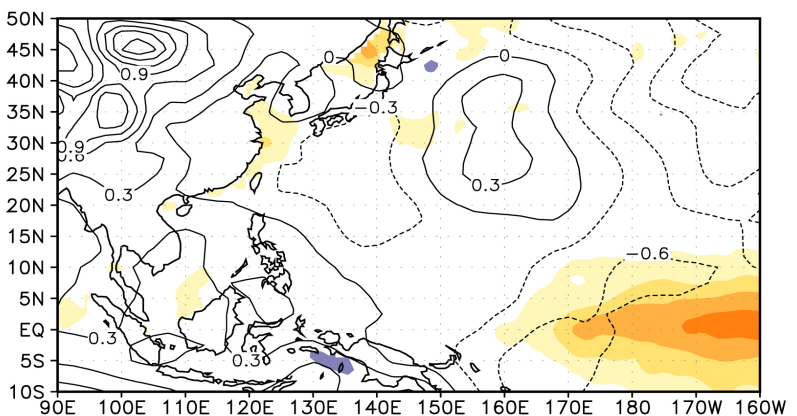

(a)

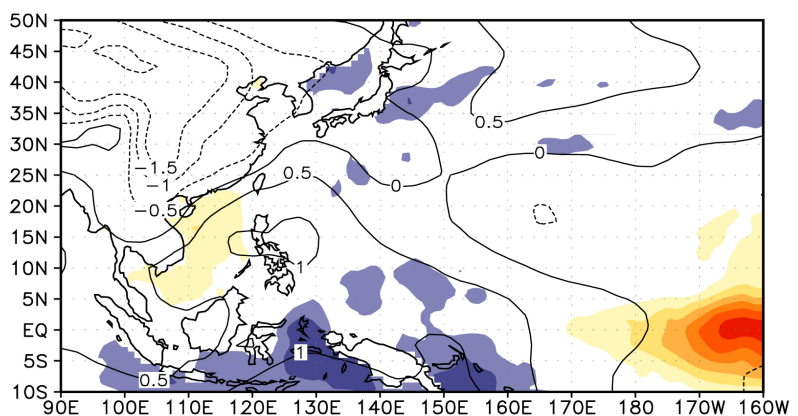

(b)

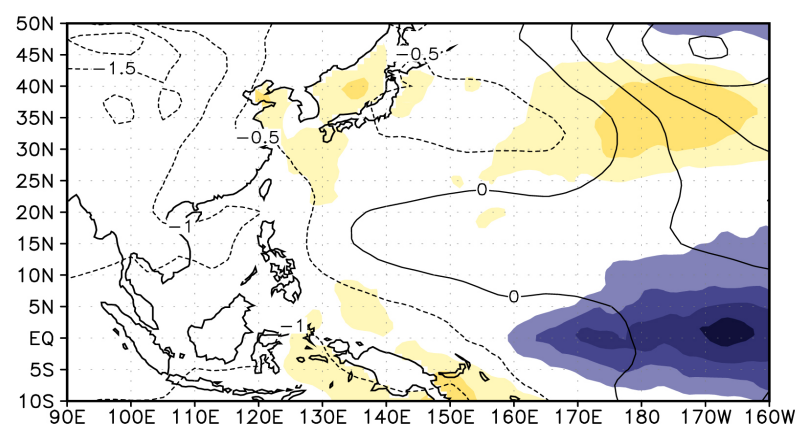

(c)

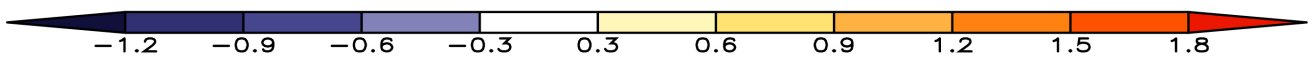

Figure 7. Composite maps of SON SST anomalies $\left({ }^{\circ} \mathrm{C}\right.$, shading) and SLP anomaly (hPa, contour) for (a) CP El Niño, (b) EP El Niño, and (c) La Niña events.

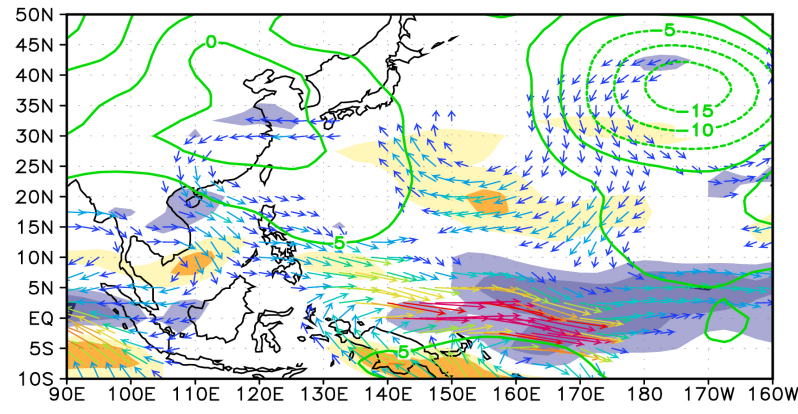

(a)

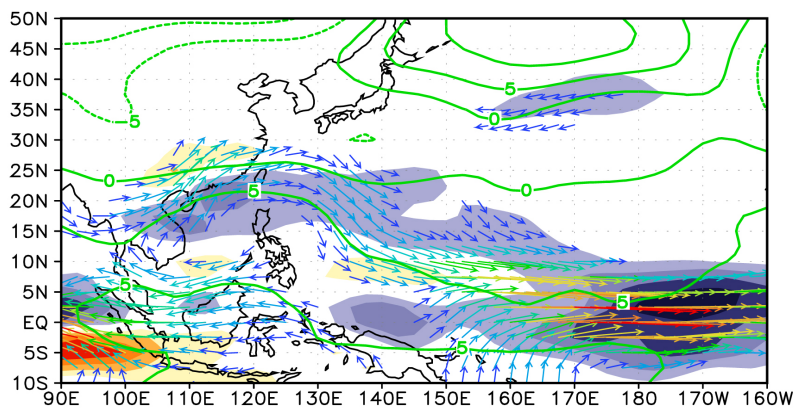

(b)

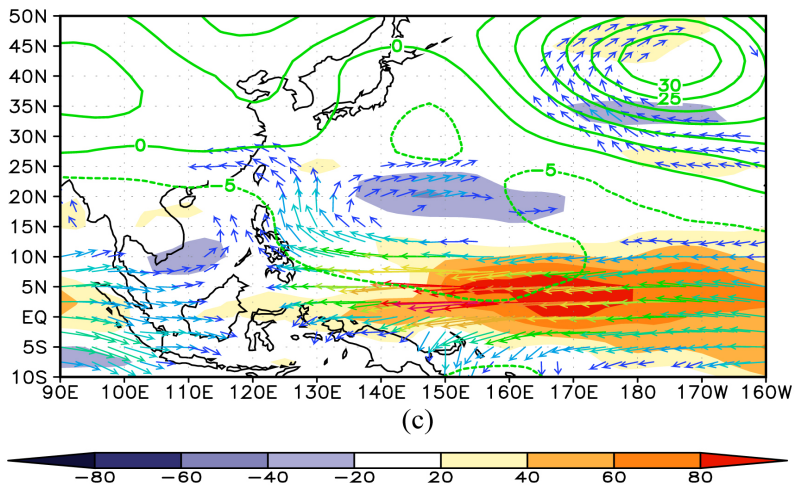

Figure 8. Composites of the magnitude and direction of the anomalous vertically integrated water vapor transport anomalies $\left(\mathrm{kg} \cdot \mathrm{m}^{-1} \cdot \mathrm{s}^{-1}\right.$, shadding and vector) and $500-\mathrm{hPa}$ geopotential height anomaly ( $\mathrm{m}$, contour) during the boreal autumn for (a) CP El Niño, (b) EP El Niño, and (c) La Niña events. 
the nearly maritime continent, the SST anomaly in EP El Niño events (Figure 7(b)) displays a marked deficit relative to CP El Niño events (Figure 7(a)). In the area near the Japan Sea, the SST anomaly shows a surplus (deficit) in CP (EP) El Niño events. The SST anomaly in La Niña (Figure 7(c)) shows a broad negative patch extending from the South American coast to $160^{\circ} \mathrm{E}$, and the mode of SST anomaly distribution is almost opposite between EP El Niño (Figure 7(b)) and La Niña (Figure 7(c)) events.

The corresponding large-scale atmospheric circulation anomalies in these three ENSO categories also exhibit distinct characteristics. In CP El Niño events (Figure $7(\mathrm{a})$ ), the pressure anomaly over the North Pacific Ocean exhibits a “-+-" structure, and the high pressure anomaly is centered near $30^{\circ} \mathrm{N}, 160^{\circ} \mathrm{E}$; in addition, a high pressure anomaly is present over the Asian continent, centered near $45^{\circ} \mathrm{N}, 100^{\circ} \mathrm{E}$ and $35^{\circ} \mathrm{N}, 97^{\circ} \mathrm{E}$. In EP El Niño events (Figure $7(\mathrm{~b})$ ), a pressure anomaly over the North Pacific Ocean displays a "+-" structure and there is a low pressure anomaly over the Asian continent, centered near $45^{\circ} \mathrm{N}, 100^{\circ} \mathrm{E}$. In La Niña events (Figure $7(\mathrm{c})$ ), the pressure anomaly over the North Pacific Ocean exhibits a "-+" structure, which is opposite to the EP El Niño events, and there is a high pressure anomaly centered near $45^{\circ} \mathrm{N}, 170^{\circ} \mathrm{W}$; furthermore, a low pressure anomaly occurs over the Asian continent, which is similar to EP El Niño events.

Figure 8 displays the composite maps of the magnitude and direction of the anomalous vertically integrated water vapor transport (IVT) and 500-hPa geopotential height anomaly during the boreal autumn for the three ENSO categories.

During CP El Niño autumns (Figure 8(a)), large negative IVT anomalies are apparent over the central Pacific and positive IVT over the North Pacific. An anomalous cyclone appears over the WNP, which can inhibit the moisture transported northward to China from the south and result in low rainfall over southern China. Moreover, the $500-\mathrm{hPa}$ anomalies exhibit a dipolar structure, with the positive anomalies over the Asian continent and negative anomalies appear over the northeast Pacific.

During the EP El Niño autumns (Figure 8(b)), large negative IVT anomalies are apparent over the central and western Pacific. The 500-hPa anomalies exhibit a dipolar structure; positive anomalies appear over the northeast Pacific and negative anomalies over Asian continent, which is the opposite to CP El Niño autumns. An anomalous anticyclone appears over the WNP, which can transport more moisture to southeastern and eastern Asia, leading to an increase in rainfall over southern China.

During La Niña autumns (Figure 8(c)), large positive IVT anomalies are apparent over the central Pacific, which is almost opposite to that occurring during EP El Niño autumns. Probably as a response to the warming SST anomaly over the western Pacific, an anomalous cyclone emerges over the WNP and is centred over the South China Sea, because this airflow is derived from the western Pacific. This causes a rainfall surplus over the middle of southwest China and deficits 
over other regions. Moreover, the 500-hPa anomalies exhibit a dipolar structure, with positive anomalies over the north Pacific and the northern Asian continent and negative anomalies over the south Pacific and the southern Asian continent.

\section{Summary}

It has been well known that the autumn rainfall over West China is one of the main causes of meteorological disasters, and the different classification of ENSO has highlighted the importance of the precipitation over China. This study analyzed the characteristics of the different ENSO types and their possible effects on autumn rainfall over southwest China.

1) Over southwest China, the autumn rainfall accounts for more than $20 \%$ of the total annual rainfall. After 1990, the autumn rainfall over the region is dominantly showed a deficit until 2011.

2) The large-scale atmospheric circulation anomalies for the three ENSO categories also exhibit distinct characteristics. In CP El Niño events, the pressure anomaly over the North Pacific Ocean exhibits a "-+-" structure. In EP El Niño events, a pressure anomaly over the North Pacific Ocean displays a "+-" structure. In La Niña events, the structure of pressure is opposite to the EP El Niño events.

3) During CP El Niño autumns, large negative IVT anomalies occur over the central Pacific and positive IVT anomalies over the North Pacific. An anomalous cyclone appears over the WNP. In EP El Niño autumns, large negative IVT anomalies are present over the central and western Pacific. An anomalous anticyclone appears over the WNP, and the structure of $500-\mathrm{hPa}$ is opposite to CP El Niño autumns. During La Niña autumns, large positive IVT anomalies are almost opposite to those occurring during EP El Niño autumns.

Thus, because of the different atmospheric responses to SST, the rainfall responses over southwest China to three types of ENSO events ate differently. The mechanism of the impact of different types of ENSO events on rainfall over southwest China requires further investigation.

\section{Acknowledgements}

This work is funded by the Undergraduate teaching Engineering of Chengdu university of Information Technology (BKJX2020057, JYJG2021034).

\section{Conflicts of Interest}

The authors declare no conflicts of interest regarding the publication of this paper.

\section{References}

Ashok, K., Behera, S. K., Rao, S. A., Weng, H. Y., \& Yamagata, T. (2007). El Niño Modoki and Its Possible Teleconnection. Journal of Geophysical Research, 112, C11007.

https://doi.org/10.1029/2006JC003798 
Bai, H., \& Dong, W. (2004). Climate Features and Formation Causes of Autumn Rain over Southwest China. Plateau Meteorology, 23, 884-889.

Bao, Y., Abulimiti, Li, F., \& Wang, X. (2003). Space-Time Distribution and Physical Mechanisms of Autumn Rains in West China in 2001. Journal of Applied Meteorological Science, 14, 215-222.

Bao, Y., Li, Y., \& Kang, Z. (2020). Characteristics and Mechanism of Monsoon Circulation Anomalies in Extrteme Autumn Rain over West China in 2017. Plateau Meteorology, 39, 560-569.

Bjerknes, J. (1969). Atmospheric Teleconnections from the Equatorial Pacific. Monthly Weather Review, 97, 163-172. https://doi.org/10.1175/1520-0493(1969)097<0163:ATFTEP >2.3.CO;2

Chen, K., Zhong, L., Hua, L. et al. (2020). Analysis on the Interdecadal Transition and Its Causes of the Autumn Precipitation Trend in West China. Climatic and Environmental Research, 25, 90-102.

Dong, B. W., Sutton, R. T., Jewson, S. P., O’Neill, A., \& Slingo, J. M. (2000). Predictable Winter Climate in the North Atlantic Sector during the 1997-1999 ENSO Cycle. Geophysical Research Letters, 27, 985-988. https://doi.org/10.1029/1999GL010994

Feng, J., \& Li, J. (2013). Contrasting Impacts of Two Types of ENSO on the Boreal Spring Hadley Circulation. Journal of Climatology, 26, 4773-4789. https://doi.org/10.1175/JCLI-D-12-00298.1

Gao, Y. (1958). On the High Autumn Clear Weather in China. Acta Meteorologica Sinica, 29, 83-92.

Harrison, D. E., \& Larkin, N. K. (1998). El Niño-Southern Oscillation Sea Surface Temperature and Wind Anomalies, 1946-1993. Reviews of Geophysics, 36, 353-400. https://doi.org/10.1029/98RG00715

He, S., Zhang, W., Qi, L., \& He, J. (2015). Contrasting SST Anomalies over the Indian Ocean between the Two Types of El Niño Events during Boreal Autumn. Acta Meteorologica Sinica, 73, 515-528.

Kalnay, E. et al. (1996). The NCEP/NCAR 40-Year Reanalysis Project. Bulletin of the American Meteorological Society, 77, 437-471. https://doi.org/10.1175/1520-0477(1996)077<0437:TNYRP>2.0.CO;2

Kao, H. Y., \& Yu, J. Y. (2009). Contrasting Eastern-Pacic and Central-Pacic Types of ENSO. Journal of Climatology, 22, 615-632. https://doi.org/10.1175/2008JCLI2309.1

Kapur, A., \& Zhang, C. (2012). Multiplicatice MJO Forcing of ENSO. Journal of Climate, 25, 8132-8147. https://doi.org/10.1175/JCLI-D-11-00609.1

Kim, H. M., \& Alexander, M. A. (2015). ENSO's Modulation of Water Vapor Transport over the Pacific-North American Region. Journal of Climatology, 28, 3846-3856. https://doi.org/10.1175/JCLI-D-14-00725.1

Kuang, X., Zhang, Y., \& Liu, J. (2008). Evolution Features of East Asian General Circulation and Mechanism during Transition Season between Autumn and Winter. Plateau Meteorology, 27, 17-25.

Kug, J. S., Jin, F. F., \& An, S. I. (2009). Two Types of El Niño Events: Cold Tongue El Niño and Warm Pool El Niño. Journal of Climatology, 22, 1499-1515. https://doi.org/10.1175/2008JCLI2624.1

Larkin, N. K., \& Harrison, D. E. (2005). On the Definition of El Niño and Associated Seasonal Average U.S. Weather Anomalies. Geophysical Research Letters, 32, L13705. https://doi.org/10.1029/2005GL022738

Liang, H., Qu, Q., Ren, R. X., Yao, Y., \& Liu, S. (2021). Impacts of Decay of Different El 
Niño Types on Boreal Summer Rainfall and Surface Air Temperature in South Asian Monsoon Region and Tibetan Plateau. Chinese Journal of Atmospheric Sciences, 45, 777-798.

Liang, J. (1989). The Regional and Seasonal Distribution of Autumn Rain in West China. Geographical Science, 9, 51-59.

Lin, X., \& Yu, S. (1993). El Niño and Rainfall during the Flood Season (June-August) in China. Acta Meteorologica Sinica, 51, 434-441.

Liu Y., Sun, L., Sun, C., Wang, Z., Wang, Y., \& Yuan, Y. (2012). Analysis of Anomalies of Autumn Rain in West China in 2011 and Its Possible Mechanism. Meteorological Monthly, 38, 456-463.

Lv, J. (1942). The Night Rain of Moment in Sichuan. Acta Meteorologica Sinica, 16, 36-53.

Rayner, N. A., Parker, D. E., Horton, E. B., Folland, C. K., Alexander, L. V., Rowell, D. P., Kent, E. C., \& Kaplan, A. (2003). Global Analyses of Sea Surface Temperature, Sea Ice, \& Night Marine Air Temperature since the Late Nineteenth Century. Journal of Geophysical Research, 108, 4407-4444. https://doi.org/10.1029/2002JD002670

Ren, H.-L., \& Jin, F.-F. (2011). Niño Indices for Two Types of ENSO. Geophysical Research Letters, 38, L04704. https://doi.org/10.1029/2010GL046031

Ropelewski, C. F., \& Halpert, M. S. (1987). Global and Regional Scale Precipitation Patterns Associated with the El Niño/Southern Oscillation. Monthly Weather Review, 115, 1606-1626. https://doi.org/10.1175/1520-0493(1987)115<1606:GARSPP>2.0.CO;2

Van Loon, H., \& Madden, R. A. (1981). The Southern Oscillation. Part I: Global Associations with Pressure and Temperature in Northern Winter. Monthly Weather Review, 109, 1150-1162. https://doi.org/10.1175/1520-0493(1981)109<1150:TSOPIG>2.0.CO;2

Wang, Q., Li, S., Fu, J., \& Li, G. (2012). On the Formation of Anomalous Summer Precipitation in the Years of 2010 and 1998: A Comparison of the El Niño's Impact between Modoki and Typical El Niño Cases. Acta Meteorologica Sinica, 70, 1207-1222. https://doi.org/10.1007/s13351-012-0601-6

Wang, Z., \& Ding, Y. (2008). Climatic Characteristics of Rainy Seasons in China. Chinese Journal of Atmospheric Sciences, 32, 1-13.

Webster, P. J., \& Yang, S. (1992). Monsoon and ENSO-Selectively Interactive Systems. Quarterly Journal of the Royal Meteorological Society, 118, 877-926. https://doi.org/10.1002/qj.49711850705

Xu, M., Zhou, B., \& Cheng, Z. (2020). Preliminary Analysis on the Interdecadal Increase of Autumn Rainfall in Western China since 2010. Transactions of Atmospheric Sciences, 43, 568-576.

Yeh, S.-W., Kug, J.-S., Dewitte, B., Kwon, M.-H., Kirtman, B. P., \& Jin, F.-F. (2009). El Niño in a Changing Climate. Nature, 461, 511-514. https://doi.org/10.1038/nature08316

Yuan, Y., Li, C., \& Yang, S. (2014). Decadal Anomalies of Winter Precipitation over Southern China in Association with El Niño and La Niña. Acta Meteorologica Sinica, 72, 237-255. https://doi.org/10.1007/s13351-014-0106-6

Yuan, Y., Yang, H., \& Li, C. (2012). Study of El Niño Events of Different Types and Their Potential Impact on the Following-Summer Precipitation in China. Acta Meteorologica Sinica, 70, 467-478.

Zanchettin, D., Franks, S. W., Traverso, P., \& Tomasino, M. (2008). On ENSO Impacts on European Wintertime Rainfalls and Their Modulation by the NAO and the Pacific Multi-Decadal Variability Described through the PDO Index. International Journal of 
Climatology, 28, 995-1006. https://doi.org/10.1002/joc.1601

Zhang, B. (1941).The Climate Region in Sichuan. Acta Meteorologica Sinica, 15, 111-144.

Zhang, C., \& Gottschalck, J. (2002). SST Anomalies of ENSO and the Madden-Julian Oscillation in the Equatorial Pacific. Journal of Climatology, 15, 2429-2445. https://doi.org/10.1175/1520-0442(2002)015<2429:SAOEAT >2.0.CO;2

Zhang, C., Wu, S., \& Huang, C. (2021). Characteristics of Atmospheric Circulation for Spring Precipitation Anomalies in Jiangxi Province and Its Response to ENSO Events. Torrential Rain and Disasters, 40, 410-418.

Zhang, W., Jin, F.-F., \& Turne, A. (2014). Increasing Autumn Drought over Southern China Associated with ENSO Regime Shift. Geophysical Research Letters, 41, 4020-4026. https://doi.org/10.1002/2014GL060130

Zhang, W., Jin, F.-F., Li, J., \& Ren, H.-L. (2011). Contrasting Impacts of Two-Type El Niño over the Western North Pacic during Boreal Autumn. Journal of the Meteorological Society of Japan, 89, 563-569. https://doi.org/10.2151/jmsj.2011-510

Zhao, S., Jin, F.-F., Long, X., \& Cane, M. (2021). On the Breakdown of ENSO's Relationship with Thermocline Depth in the Central-Equatorial Pacific. Geophysical Research Letters, 48, L092335. https://doi.org/10.1029/2020GL092335

Zheng, R., Liu, J., \& Ma, Z. (2018). Impacts of the Summertime Warm Pool in the West Pacific on Huaxi Autumn Rain and Its Possible Physical Mechanism. Acta Meteorologica Sinica, 76, 714-725.

Zhi, H., Yu, Y., Yan, L., Zhang, W., \& Li, Z. (2012). Retrospective Prediction in a Coupled Model over East Asia during El Niño Decaying Phase. Acta Meteorologica Sinica, 70, 779-788. 